СИНТЕЗ ТА АНАЛІЗ БІОЛОГІЧНО АКТИВНИХ РЕЧОВИН

\title{
DETERMINATION OF THE CONTENT OF BENZOCAINE AND PENICILLIN-G-PROCAINE IN COMBINED FINISHED DOSAGE FORMS USING TROPAEOLIN O AZO DYE
}

\author{
M.Ya.Smolinska, I.Ya.Kotsiumbas, G.Yu.Teslyar, M.V.Yurkevych \\ State Scientific-Research Control Institute of Veterinary Medicinal Products and Feed Additives \\ Key words: benzocaine; penicillin-G-procaine; tropaeolin O; spectrophotometry; combined medicines
}

\begin{abstract}
The paper presents the results of developing the method for quantitative determination of benzocaine and penicillin-G-procaine in seven combined medicines and veterinary medicinal products of different dosage forms - ointments, suppositories and tablets. The content of the medicinal substances was determined spectrophotometrically according to the absorbance intensity of the coloured product of diazotized amine azocoupling with the acid monoazo dye tropaeolin $O$. The presence of other biologically active substances (streptomycin, neomycin, prednisolone, nitrofuran, chloramphenicol, bismuth subgallate, papaverine, extracts of buckthorn and belladonna, vitamin A, menthol, xeroform, and zinc oxide), which are often found in medicines, does not prevent determination of benzocaine and penicillin-G-procaine by of the method developed. The results obtained using the method developed are consistent with those received by the direct UV-spectrophotometry and nitritometric titration after the preliminarily extraction separation of the components.
\end{abstract}

The complexity of the analysis of medicines containing more than one medicinal substance is often caused by the necessity of a quite complicated sample preparation and/or the use of the appropriate selective methods. The application of high-performance liquid chromatography (HPLC) in most cases allows determining medicines without any special difficulties. However, in Ukraine, there has still been a problem of availability of HPLC equipment for industrial and control laboratories. In such cases, the spectrophotometric method may be an alternative if there are the methods that use selective reagents to obtain the coloured analytical form of the substance to be determined.

In medical and veterinary practice to treat infectious diseases the combined medicines (CM) are widely used, they contain derivatives of $p$-aminobenzoic acid and some more medicines of different nature, such as antibiotics, vitamins, plant extracts, etc. In particular, benzocaine (BC) and penicillin-G-procaine (PGP) are used in such medicines. The former is used as a local anesthetic, while the latter - as an antibiotic in the form of an associate with anesthetic procaine $[1,5]$.

There are publications, which describe methods of spectrophotometric determination of $\mathrm{BC}[7,8,10,11$, $14,15]$ and PGP according to procaine $[6,12,13]$ in the presence of other components of the medicine. At the same time, the effect on the analytical response of these components, including medicinal substances, has not been studied so far. The current normative documents regulating determination of the content for $\mathrm{BC}$ and $\mathrm{PGP}$ in
CM involve HPLC methods, direct spectrophotometry or titrimetric analysis. In these cases, the measurement is always preceded by the implementation of the appropriate procedures of separation of drug components. In 2015 we developed the method for determination of amide and ester of aminobenzoic acid in liquid medicinal forms by the spectrophotometric method. In this method the acid monoazo dye tropaeolin $\mathrm{O}(\mathrm{TrO})$ is used in the azocoupling reaction with analytes in the form of diazotized amines to obtain the analytical form, namely a coloured diazo compound [4]. Earlier, the similar approach was successfully used to the selective determination of sulfonamides in the drug tablet form [9].

The aim of our study was to determine the content of $\mathrm{BC}$ and PGP in CM according to the method based on diazotization of aromatic amines followed by azocoupling of the diazo salt formed with TrO. The resulting blue coloured product has the absorbance maximum at the wavelength of $\lambda_{\max }=595-600 \mathrm{~nm}$ and the molar absorptivity of $\varepsilon_{\lambda} \approx 10^{4} \mathrm{M}^{-1} \mathrm{~cm}^{-1}$ (Fig.).

The optimal conditions for obtaining the coloured product of the azocoupling reaction of $\mathrm{BC}$ and PGP diazo salt with the azo dye TrO, namely nitrozo diazo dye, as well as the spectrophotometric specifications and validation parameters of the method are presented in Tab. 1 [4].

\section{Materials and Methods}

As the objects of the study the following $\mathrm{CM}$ were used: "Mastivil" ointment, Vilsan, Turkey (veterinary medicinal product); "Multidject IMM" ointment, Norbrook Laboratories Ltd., Northern Ireland (veterinary medicinal 


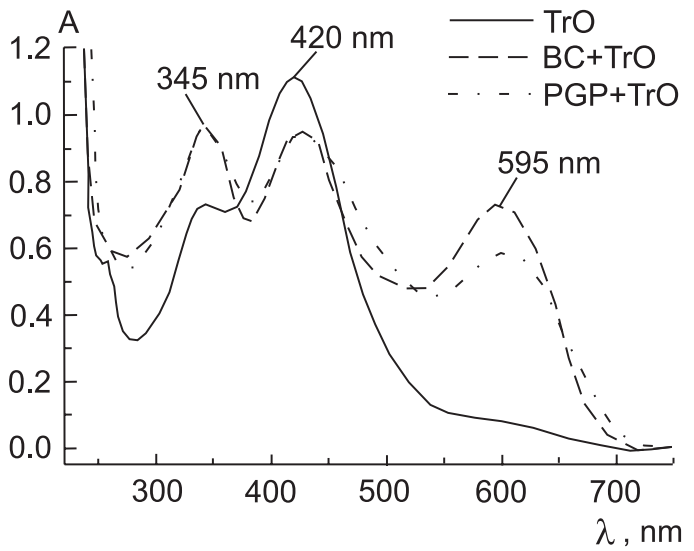

Fig. Absorption spectra of $\mathrm{TrO}$ solution and solutions of the products of $\mathrm{TrO}$ interaction with $\mathrm{BC}$ and PGP.

product); "Protective ointment Forte" LLC "Farmaton" Firm, Rivne, Ukraine (veterinary medicinal product); "Dyvoprayd" rectal suppositories PLS MSE "Ukrzoovetprompostach" Kyiv, Ukraine (veterinary medicinal product); "Fastin" ointment PJSC “Lubnyfarm" Lubny, Ukraine; "Anestezol" rectal suppositories JSC "LekhimKharkiv" Kharkiv, Ukraine; "Bellasthesin" tablets PJSC SIC "Borshchahivskiy CPP”, Kyiv, Ukraine.

The substances of BK and PGP (Sigma, USA, the content of the active substance was not less than 99\%) were used as a standard sample (SS) to prepare the corresponding solution of the working standard (WS).

The biologically active substances of streptomycin, neomycin, prednisolone, nitrofuran, chloramphenicol, bismuth subgallate, papaverine, extracts of buckthorn and belladonna, vitamin A, menthol, xeroform, and zinc oxide (the content of the active substance was not less than $99 \%$ ) were used for preparation of mixtures with $\mathrm{BC}$ and PGP when studying selective interactions.

Highly purified water [3] was used for preparation of aqueous solutions and aqueous mixtures, and a folded filter of the "White Ribbon" filter paper was used for their filtration.

As a reagent the solution of $\mathrm{TrO}$ (Merck, Germany) was used; it was prepared by dissolving an accurate weight of the reagent of the analytical grade purity (the content of the active substance was not less than $88 \%$ ) in distilled water.

The solutions of sodium nitrite, hydrochloric acid, sodium hydroxide, and sodium tetraborate were prepared from the reagents of the analytical grade purity by dissolving in distilled water.

UV-VIS measurements were performed with a scanning spectrophotometer (CARY.WIN UV-VIS-50, Varian, USA) using $1 \mathrm{~cm}$ cells. All absorbance measurements were performed at $20-25^{\circ} \mathrm{C}$. The $\mathrm{pH}$ value was measured by the RV $11 \mathrm{pH}-$ meter (Sartorius, Germany) equipped with a combined electrode incorporating both glass and reference silver chloride electrodes into one body. The required $\mathrm{pH}$ of each solution was adjusted using $\mathrm{HCl}$ and $\mathrm{NaOH}$ solutions.

Preparation of the working test sample (WTS) solution for PGP determination in the ointment

Place an accurately weighed sample of the ointment containing $45 \mathrm{mg}$ of PGP into a chemical glass, and add $50 \mathrm{ml}$ of water. Heat the mixture on a water bath at the

Description of the methods of determination of BC and PGP with TrO

\begin{tabular}{|c|c|c|}
\hline \multicolumn{3}{|c|}{ The optimal conditions for obtaining the maximum analytical signal } \\
\hline Characteristic & $\mathrm{BC}$ & PGP \\
\hline \multicolumn{3}{|c|}{ Diazotization } \\
\hline Concentration of $\mathrm{HCl}$ & \multicolumn{2}{|c|}{$0.5-1.0 \mathrm{Mol}^{-1} \mathrm{f}^{-1}$} \\
\hline Concentration of $\mathrm{NaNO}_{2}$ & \multicolumn{2}{|c|}{$\geq 4.0 \cdot 10^{-3} \mathrm{Mol} \cdot \mathrm{I}^{-1}$ ( 100-fold excess) } \\
\hline The order of addition of reagents & \multicolumn{2}{|c|}{$\left[\mathrm{HCl}+\mathrm{BC}(\mathrm{PGP})+\mathrm{NaNO}_{2}\right]$} \\
\hline Reaction time & \multicolumn{2}{|c|}{$20 \min$ at $20^{\circ} \mathrm{C}\left(10 \mathrm{~min}\right.$ at $\left.0^{\circ} \mathrm{C}\right)$} \\
\hline \multicolumn{3}{|c|}{ Azocoupling } \\
\hline Amount of TpO & \multicolumn{2}{|c|}{ 2-fold excess } \\
\hline Concentration of $\mathrm{Na}_{2} \mathrm{~B}_{4} \mathrm{O}_{7}$ & \multicolumn{2}{|c|}{$0.01 \mathrm{Mol}^{-1} \mathrm{I}^{-1}$} \\
\hline $\mathrm{pH}$ & \multicolumn{2}{|c|}{$10-11.5$} \\
\hline The order of addition of reagents & \multicolumn{2}{|c|}{$\left[\mathrm{BC}_{\text {diaz. }}\left(\mathrm{PGP}_{\text {diaz }}\right)+\mathrm{TrO}+\mathrm{Na}_{2} \mathrm{~B}_{4} \mathrm{O}_{7}+\mathrm{NaOH}\right] \mathrm{pH}$} \\
\hline Stability & \multicolumn{2}{|c|}{$1 \mathrm{~h}$} \\
\hline \multicolumn{3}{|c|}{ Spectrophotometric characteristics of the method of determination } \\
\hline$\lambda_{\max }$ & 595 & 595 \\
\hline$\varepsilon_{595} \cdot 10^{-4}, \mathrm{M}^{-1} \mathrm{~cm}^{-1}$ & 1.98 & 1.59 \\
\hline \multicolumn{3}{|c|}{ Metrological characteristics of the method of determination } \\
\hline Optimum photometric linear range, $\mu \mathrm{g} \cdot \mathrm{ml}^{-1}$ & $0.4-8.0$ & $2.0-35.4$ \\
\hline Calibration equation, $\mu \mathrm{g} \cdot \mathrm{ml}^{-1}$ & $\Delta \mathrm{A}=0.013+0.120 \cdot \mathrm{C}$ & $\Delta \mathrm{A}=-0.008+0.028 \cdot \mathrm{C}$ \\
\hline Limit of Detection, $\mu \mathrm{g} \cdot \mathrm{ml}^{-1}$ & 0.14 & 0.57 \\
\hline Limit of Quantification, $\mu \mathrm{g} \cdot \mathrm{ml}^{-1}$ & 0.42 & 1.71 \\
\hline $\mathrm{R}^{2}$ & 0.9993 & 0.9993 \\
\hline
\end{tabular}


temperature of approximately $80^{\circ} \mathrm{C}$ to complete the melting of the ointment. Filter the mixture obtained into a $100 \mathrm{~mL}$ volumetric flask (keep the glass with the mixture in hot water bath to prevent solidification of the sample till completion of filtration). Then wash the filter 3-4 times with hot water. Cool the filtrate, dilute the flask to the volume with the same solvent and mix thoroughly.

Preparation of WTS solution for BC determina-

\section{tion in tablets}

Place an accurately weighed sample of powdered tablets containing $125 \mathrm{mg}$ of $\mathrm{BC}$ into a $100 \mathrm{~mL}$ volumetric flask and dissolve in $50 \mathrm{~mL}$ of ethanol for at least $10 \mathrm{~min}$ to obtain the $\mathrm{BC}$ extract, and dilute the content of the flask to the volume with the same solvent. Mix thoroughly the solution obtained, filter it into a conical flask, discard the first $10-15 \mathrm{ml}$ of the filtrate. Place $5.0 \mathrm{~mL}$ of the filtrate into a $25 \mathrm{~mL}$ volumetric flask; dilute the flask to the volume with ethanol and mix thoroughly.

Preparation of WTS solution for BC determination in the ointment or suppositories

Place an accurately weighed sample of the ointment or suppositories containing $125 \mathrm{mg}$ of BC into a $100 \mathrm{~mL}$ volumetric flask and dilute to the volume with ethanol. Mix thoroughly the solution obtained and filter into a conical flask, discard the first 10-15 ml of the filtrate. Dilute the filtrate 5 times as in the case of sample preparation for tablets.

Preparation of WSS solution for PGP determination

Place $22 \mathrm{mg}$ of SS of PGP (accurate weight) into a $50 \mathrm{~mL}$ volumetric flask and dissolve in $30 \mathrm{~mL}$ of water, dilute the content of the flask to the volume with the same solvent and mix thoroughly.

Preparation of WSS solution for BC determination

Place $31 \mathrm{mg}$ of SS of BC (accurate weight) into a $25 \mathrm{~mL}$ volumetric flask and dissolve in $15 \mathrm{~mL}$ of water, dilute the content of the flask to the volume with the same solvent and mix thoroughly. Dilute the filtrate 5 times with the same solvent.

The general procedure of PGP or BC determination with TrO

Place sequentially $5.0 \mathrm{ml}$ of $0.5 \mathrm{M}$ hydrochloric acid solution, $0.5 \mathrm{ml}$ of WSS solution (WTS solution), and $0.5 \mathrm{ml}$ of $0.15 \mathrm{M}$ sodium nitrite solution into a $25 \mathrm{ml}$ volumetric flask. Stir and cool the solution obtained on an ice bath for $10 \mathrm{~min}$. Then add $0.5 \mathrm{ml}$ of $3.0 \cdot 10^{-3} \mathrm{M}$ TrO solution and $2.5 \mathrm{ml}$ of $0.1 \mathrm{M}$ sodium tetraborate solution into the flask. Neutralize the mixture obtained by adding the sodium hydroxide solution adjusting the $\mathrm{pH}$ value to 10.5 . Dilute to the volume of $25 \mathrm{ml}$ with distilled water. Then mix the solution thoroughly and measure the intensity of light absorption (at the room temperature $\sim 293 \mathrm{~K}$ ) for all blank solutions of the corresponding reagents at $\lambda=595 \mathrm{~nm}, l=1.0 \mathrm{~cm}$.

The content of PGP $(X)$ in the ointment test sample $(\mathrm{mg} / \mathrm{g})$ was calculated using the formula:

$$
X=\frac{E_{1} \cdot m_{2} \cdot P_{1} \cdot 100}{E_{2} \cdot m_{1} \cdot 100 \% \cdot 50}=\frac{E_{1} \cdot m_{2} \cdot P_{1}}{E_{2} \cdot m_{1} \cdot 50},
$$

where: $E_{1}$ - is the absorbance value of WTS solution of the ointment; $E_{2}-$ is the absorbance value of WSS solution of SS of PGP; $m_{1}-$ is the test sample weight of the ointment containing PGP, $g ; m_{2}-$ is the standard sample weight of PGP, $\mathrm{mg} ; P_{1}-$ is the content of the active substance in $\mathrm{SS}$ of PGP according to the quality certificate of the manufacturer, $\% ; 100-$ is the dilution factor of the test sample of the ointment; 50 - is the dilution factor of SS of PGP; $100 \%$ - is the conversion factor of percentage in unit fraction.

The content of BC $(Y)$ in the ointment test sample $(\mathrm{mg} / \mathrm{g})$ was calculated using the formula:

$$
Y=\frac{E_{1} \cdot m_{2} \cdot P_{2} \cdot 500}{E_{2} \cdot m_{1} \cdot 100 \% \cdot 125}=\frac{E_{1} \cdot m_{2} \cdot P_{2}}{E_{2} \cdot m_{1} \cdot 25}
$$

where: $E_{1}$ - is the absorbance value of WTS solution of the ointment; $E_{2}-$ is the absorbance value of WSS solution of SS of BC; $\mathrm{ml}$ - is the test sample weight of the ointment containing $\mathrm{BC}, \mathrm{g} ; m_{2}-$ is the standard sample weight of BC, mg; $P_{2}$ - is the content of the active substance in $\mathrm{SS}$ of $\mathrm{BC}$ according to the quality certificate of the manufacturer, $\% ; 500-$ is the dilution factor of the test sample of the ointment; 125 - is the dilution factor of SS of $\mathrm{BC} ; 100 \%$ - is the conversion factor of percentage in unit fraction.

The content of $\mathrm{BC}(Z)$ in a tablet $(\mathrm{mg} / \mathrm{tbl})$ or in a suppository ( $\mathrm{mg} / \mathrm{sps}$ ) was calculated using the formula:

$$
Z=\frac{E_{1} \cdot m_{2} \cdot P_{2} \cdot m_{3} \cdot 500}{E_{2} \cdot m_{1} \cdot 100 \% \cdot 125}=\frac{E_{1} \cdot m_{2} \cdot P_{2} \cdot m_{3}}{E_{2} \cdot m_{1} \cdot 25},
$$

where: $E_{1}$ - is the absorbance value of WTS solution of the tablet powder or suppositories; $E_{2}-$ is the absorbance value of WSS solution of SS of BC; $m_{1}-$ is the test sample weight of the tablet powder or suppositories containing $\mathrm{BC}, \mathrm{g} ; m_{2}-$ is the standard sample weight of BC, mg; $P_{2}-$ is the content of the active substance in $\mathrm{SS}$ of $\mathrm{BC}$ according to the quality certificate of the manufacturer, $\% ; m_{3}-$ is the average weight of a tablet $(\mathrm{g} / \mathrm{tbl})$, or a suppository $(\mathrm{g} / \mathrm{sps}) ; 500$ - is the dilution factor of the test sample of the tablet powder or suppositories; 125 - is the dilution factor of SS of $\mathrm{BC} ; 100 \%$ - is the conversion factor of percentage in unit fraction.

The research results were processed in accordance with the recommendations of the State Pharmacopoeia of Ukraine [2] using the methods of mathematical statistics. The study of selectivity was conducted on the model solutions by the "introduced - found" method. The content of BC and PGP in the finished dosage forms was determined by the method of standard.

\section{Results and Discussion}

Since CM containing BC and PGP include one or more medicinal substances in addition to the excipients, their effect on determination of aromatic amines with TrO was studied. The selectivity of the methods developed for mixtures containing additional medicinal substances in amounts that greatly exceeded their possible content in the medicine was analysed. The permanence of absorbance of the solutions of the coloured products formed within $5 \%$ was chosen to be the criterion for the selectivity of determination. The research results are given in Tab. 2. 
The results of determination of $\mathrm{BC}$ and $\mathrm{PGP}$ with $\mathrm{TrO}$ in the presence of various amounts of additional medicinal substances (AMS) in the samples studied

\begin{tabular}{|c|c|c|c|c|}
\hline $\begin{array}{l}\text { Medicines } \\
\text { determined }\end{array}$ & AMS & $\begin{array}{c}\mathrm{m}(\mathrm{BC}(\mathrm{PGP})): \\
\mathrm{m}(\mathrm{AMS})^{*}\end{array}$ & $\begin{array}{c}\mathrm{m}(\mathrm{BC}(\mathrm{PGP})): \\
\mathrm{m}(\mathrm{AMS})^{* *}\end{array}$ & $\begin{array}{l}\text { \% The content of BC } \\
\text { (PGP) found, } \\
\bar{x} \pm S \cdot t_{\alpha} / \sqrt{n}\end{array}$ \\
\hline \multirow{10}{*}{$B C$} & Vitamin A & $1: 0.2$ & $1: 1$ & $99.8 \pm 1.1$ \\
\hline & zinc oxide & $1: 2$ & $1: 25$ & $101.8 \pm 1.5$ \\
\hline & xeroform & $1: 0.4$ & $1: 10$ & $99.1 \pm 1.6$ \\
\hline & menthol & 1:0.08 & $1: 1$ & $100.5 \pm 1.4$ \\
\hline & nitrofuran & 1:0.67 & $1: 5$ & $95.3 \pm 2.1$ \\
\hline & chloramphenicol & 1:0.5 & $1: 1$ & $95.4 \pm 1.9$ \\
\hline & bismuth subgallate & $1: 0.4$ & $1: 10$ & $97.4 \pm 2.2$ \\
\hline & buckthorn extract & $1: 1$ & $1: 2$ & $96.0 \pm 2.1$ \\
\hline & belladonna extract & 1:0.05 & $1: 1$ & $95.8 \pm 2.3$ \\
\hline & papaverine & 1:0.17 & $1: 2$ & $98.1 \pm 2.2$ \\
\hline \multirow{3}{*}{ PGP } & streptomycin & $1: 1$ & $1: 10$ & $97.0 \pm 1.3$ \\
\hline & neomycin & $1: 1$ & $1: 5$ & $95.2 \pm 1.6$ \\
\hline & prednisolone & 1:0.1 & $1: 1$ & $97.5 \pm 1.4$ \\
\hline
\end{tabular}

Note: * the mass ratios of $B C(P G P)$ and AMS, which are present in the medicines tested; ** - the maximum mass ratios of BC (PGP) and AMS modelled to study.

The results of our study show that the hindering effect of additional medicinal substances appears only when they are used in much larger quantities than those typically found in medicines and veterinary medicinal products. Therefore, it is arguable that the additional medicinal substances studied do not prevent the interaction of PGP or BC with $\mathrm{TrO}$ when forming coloured analytical forms.

The results of spectrophotometric determination of BC and PGP with TrO in the CM studied

Obtained by the method, described in the regulations

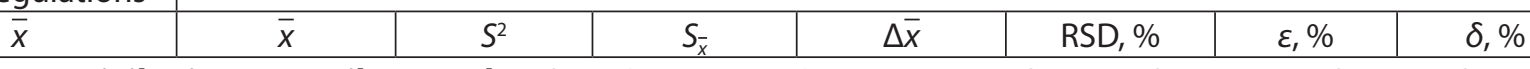

1. "Mastivil" ointment, Vilsan, Turkey $(P G P(20 \pm 10 \mathrm{mg} / \mathrm{g})$, streptomycin $(20 \mathrm{mg} / \mathrm{g})$, neomycin $(20 \mathrm{mg} / \mathrm{g})$, prednisolone ( $2 \mathrm{mg} / \mathrm{g})$, sorbitan monostearate, liquid paraffin)
9.42
19.90
0.3323
0.2572
0.71
2.89
3.57
$+2.58$

2. "Multidject IMM" ointment, Norbrook Laboratories Ltd., Northern Ireland (PGP (22 2 mg/g), streptomycin (20 mg/g), neomycin (22 mg/g), prednisolone (2,2 mg/g), liquid paraffin, white soft paraffin)
21.81
21.53
0.1696
0.1842
0.51
1.91
2.37
$-1.24$

3. "Protective ointment Forte" LLC “Farmaton" Firm, Rivne, Ukraine (BC (25 $\pm 2.5 \mathrm{mg} / \mathrm{g})$, vitamin A (5 mg/g), zinc oxide (50 mg/g), anthracin, sodium dodecyl, PEG-1500, PEG-400)

\begin{tabular}{l|l|l|l|l|l|l|l|}
24.83 & 24.27 & 0.2290 & 0.2140 & 0.59 & 1.97 & 2.45 & -2.26
\end{tabular}

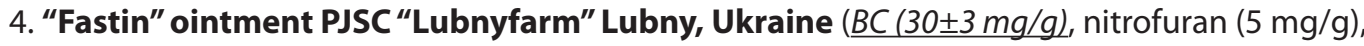
chloramphenicol $(5 \mathrm{mg} / \mathrm{g})$, lanoline, vaseline, stearic acid, water)
29.65

29.32
0.1079
0.1469
0.41
1.12
1.40
$-1.13$

5. “Dyvoprayd" rectal suppositories PLS MSE “Ukrzoovetprompostach” Kyiv, Ukraine ( $\underline{B C}(14.7 \pm 1 \mathrm{mg} / \mathrm{g})$, buckthorn extract (50 mg/g), xeroform ( $20 \mathrm{mg} / \mathrm{g})$, zinc oxide ( $20 \mathrm{mg} / \mathrm{g})$, menthol $(4 \mathrm{mg} / \mathrm{g})$, PEG-400, PEG-1500)
31.11
31.00
0.1923
0.1961
0.54
1.41
1.8
$-0.32$

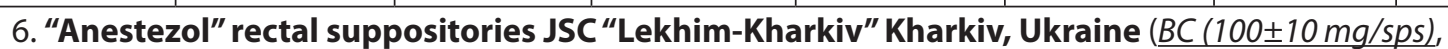

bismuth subgallate (40 mg/sps), menthol (4 mg/sps), zinc oxide (20 mg/sps), PEG-400, PEG-1500)
97.74
99.00
2.4655
0.7022
1.95
1.59
1.97
$+1.23$

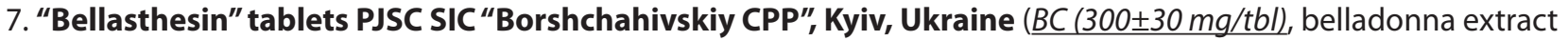
(15 mg/tbl), menthol (4 mg/tbl), zinc oxide (20 mg/tbl), microcrystalline cellulose, sodium croscarmellose, calcium stearate, copovidone, mannitol) 
The results obtained allowed us to apply the method developed to the analysis of the PGP and BC content in combined medicines and veterinary medicinal products. In parallel, the content of BC and PGP was determined by the methods described in the current regulations, namely nitritometric titration and direct UV spectrophotometric determination after the previous separation of the drug components. The results are shown in Tab. 3 .

According to Tab. 3 the results of BC and PGP determination with $\mathrm{TrO}$ are consistent with the results obtained by the methods described in the regulations for the medicines studied. The method developed is highly selective towards the medicinal substances determined; it is simple and rapid as it does not require prior separation of additional medicinal substances in contrast to nitritometric titration, UV spectrophotometry and other methods of determination described in the literature.

\section{CONCLUSIONS}

1. A rapid and selective method for the spectrophotometric determination of BC and PGP in combined medicines and veterinary medicinal products has been developed; it is based on measurements of absorbance intensity of coloured products of azocoupling of their diazo salts with acid monoazo dye TrO.

2. The effect of some common medicinal substances and excipients on determination of BC and PGP using azo dye TrO applied in the method developed has been studied. It has been found that medicinal substances and excipients studied, which are part of the registered medicines, do not interfere with determination.

3 . Seven combined medicines and veterinary medicinal products (ointments, suppositories and tablets) have been analyzed to determine the content of BC and PGP. The results are consistent with the ones obtained by the methods described in the regulations.

\section{REFERENCES}

1. Арзамасиев А.П. Фармачевтическая химия: Учеб. пособие / Под ред. А.П.Арзамасиева. - М.: ГОЭТАРМЕД, 2004. - 640 c.

2. Держсавна фармакопея Украйни / Державне підприємство «Науково-експертний фармакопейний центр». 1-е вид. - Доп. 1. - Х.: РІРЕГ, 2004. - 520 c.

3. Державна фармакопея Украйни / Державне підприємство «Науково-експертний фармакопейний центр». 1-е вид. - Доп. 4. - Х.: РІРЕГ, 2011. - 520 c.

4. Смолінська М.Я., Кочюмбас І.Я., Тесляр Г.Ю. та ін. // Фармаи. журн. - 2015. - №2. - С. 59-68.

5. Ятусевич А.И., Толкач Н.Г., Ятусевич И.А., Панковеи Е.А. Лекарственные средства в ветеринарной медииине: Справочник. - Мн: Техноперспектива, 2006. - 403 c.

6. Al-Abachi M.Q., Al-Uzri W.A. // J. Baghdad for Sci. - 2012. - Vol. 9, №3. - P. 521-531.

7. Al-Abdaly Z.Z. // J. Raf. Sci. - 2009. - Vol. 20, №1. - P. 38-46.

8. Amin A.S., El-Didamony A.M. // Anal. Sci. - 2003. - Vol. 19, №10. - P. 1457-1459.

9. Boiko M., Vrublevska T., Korkuna O. Teslyar G. // Spectrochim. Acta A. - 2011. - Vol. 79A, №2. - P. 325-331.

10. Madrakian T., Shamsipur M., Afkhami A. // J. Sci., Islamic Republic of Iran. - 2002. - Vol. 13, №2. - P. 121-124.

11. Mohammed D.H., Sarsam L.A. // J. University of Anbar for Pure Sci. - 2011. - Vol. 5, №1. - P. 24-30.

12. Morelli B. // J. Pharm. Biomed. Anal. - 1995. - Vol. 13, №3. - P. 219-227.

13. Murillo Pulgarín J.A., Alanon Molina A. // Anal. Lett. - 1993. - Vol. 26, №9. - P. 1919-1932.

14. Paschoal L.R., Ferreira W.A. // Il Farmaco. - 2000. - Vol. 55, №11-12. - P. 687-693.

15. Pasekova H., Polasek M. // Talanta. - 2000. - Vol. 52, №1. - P. 67-75.

\section{ВИЗНАЧЕННЯ ВМІСТУ БЕНЗОКАЇНУ ТА ПЕНІЦИЛІН-G-ПРОКАЇНУ У СКЛАДІ КОМБІНОВАНИХ ГОТОВИХ ЛІКАРСЬКИХ ФОРМ 3 ВИКОРИСТАННЯМ АЗОБАРВНИКА ТРОПЕОЛІНУ $О$ \\ М.Я.Смолінська, І.Я.Коцюмбас, Г.Ю.Тесляр, М.В.Юркевич}

Ключові слова: бензокаїн; пеніцилін-G-прокаїн; тропеолін О; спектрофоотометрія; комбіновані лікарські препарати

Викладені результати розробки методики кількісного визначення бензокаїну та пеніцилінG-прокаїну за прокаїном у семи комбінованих лікарських препаратах різних лікарських форм мазях, супозиторіях і таблетках. Вміст цих лікарських речовин визначали спектрофотометричним методом за інтенсивністю світлопоглинання кольорових продуктів їх діазосолей з кислотним моноазобарвником тропеоліном О. Визначенню бензокаїну та пеніцилін-G-прокаӥну за розробленою методикою не перешкоджає присутність інших біологічно активних речовин (стрептоміцину, неоміцину, преднізолону, нітроффурану, хлорамсенніколу, вісмуту субгалату, папаверину, екстрактів обліпихи і красавки, вітаміну А, ментолу, ксерофрорму, цинку оксиду), що входять у багатьох випадках до складу лікарських препаратів. Результати, одержані за допомогою розробленої методики, узгоджуються з результатами, отриманими методами прямої УФ-спектрофоотометрії та нітритометрії після попередньо проведеного екстракційного розділення компонентів препаратів. 
ОПРЕДЕЛЕНИЕ СОДЕРЖАНИЯ БЕНЗОКАИНА И ПЕНИЦИЛЛИН-G-ПРОКАИНА В СОСТАВЕ КОМБИНИРОВАННЫХ ГОТОВЫХ ЛЕКАРСТВЕННЫХ ФОРМ С ИСПОЛЬЗОВАНИЕМ АЗОКРАСИТЕЛЯ ТРОПЕОЛИНА О

М.Я.Смолинская, И.Я.Коцюмбас, Г.Ю.Тесляр, М.В.Юркевич

Ключевые слова: бензокаин; пенициллин-G-прокаин; тропеолин О; спектрофоотометрия; комбинированные лекарственные препараты

Изложены результаты разработки методики количественного определения бензокаина и пенициллин-G-прокаина по прокаину в семи комбинированных лекарственных и ветеринарных препаратах разных лекарственных форм - мазях, суппозиториях и таблетках. Содержание указанных лекарственных веществ определяли спектрофотометрическим методом по интенсивности светопоглощения окрашенного продукта азосочетания диазотированного амина с кислотным моноазокрасителем тропеолином О. Определению бензокаина и пенициллинG-прокаина по разработанной методике не препятствует наличие других биологически активных веществ (стрептомицина, неомицина, преднизолона, нитрофрурана, хлорамфреникола, висмута субгалата, папаверина, экстрактов облепихи и красавки, витамина $A$, ментола, ксероформа, цинка оксида), входящих во многих случаях в состав лекарственных препаратов. Результаты, полученные с помощью разработанной методики, согласуются с результатами, полученными методами прямой УФ-спектрофоотометрии и нитритометрии после предварительно проведенного экстракционного разделения компонентов. 